\section{Close shave for Austrian science budget}

The Austrian government has retreated from its threat to cut the science budget by $40 \%$ (see Nature 457, 648; 2009), approving instead a small rise that slows rather than reverses the country's plans for a big expansion in science.

The FWF, Austria's principal researchfunding agency, has had its money cut by $18 \%$, but president Christoph Kratky says the new budget stability makes up for the shortfall. In the next few weeks the FWF will clear a backlog of 700 reviewed projects accumulated over six months of uncertainty.

The Austrian Academy of Sciences, which runs 33 research institutes, gets a bare $2 \%$ rise, although it has recently opened several new institutes. Outgoing academy president Peter Schuster says that these - including the Centre for Molecular Medicine and the Institute of Molecular Biotechnology, both in Vienna - will be sheltered from cuts. The academy is now deciding where to wield the knife among the older institutes.

For a longer version of this story, see http://tinyurl.com/cnahq3.

\section{Nobel laureate celebrates her centenary}

The Italian neuroscientist Rita Levi-

Montalcini became the first Nobel laureate to reach the age of 100, on 22 April. During birthday celebrations at a scientific meeting in Rome, Italian education minister Maria Stella Gelmini announced two gifts to honour her.

One was a $€ 500,000$ (US\$650,000) oneoff sum to the research institute that LeviMontalcini founded, the European Brain Research Institute in Rome, which is close to bankruptcy (see Nature 458, 564-567; 2009). The second was a $€ 6$-million programme, named after her, to return 30 young scientists working abroad to Italy on three-year grants.

Many scientists criticized the donations as drops in the ocean, but Levi-Montalcini said the gestures were more than she had dared

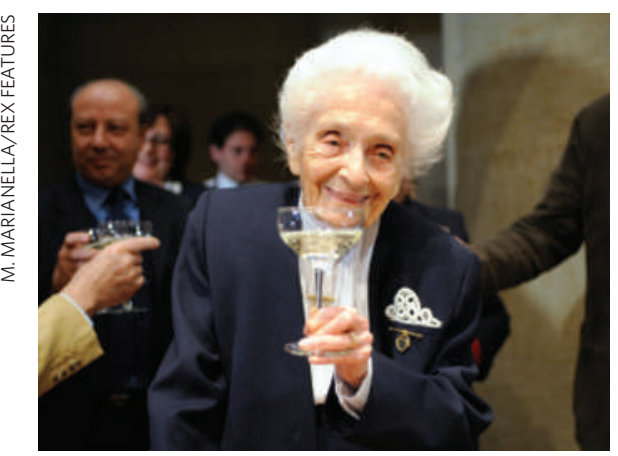

Rita Levi-Montalcini: first Nobel centenarian.

\title{
Researchers rally to support animal studies
}

Advocates for research outnumbered animal-rights activists by ten to one at a peaceful demonstration last week at the University of California, Los Angeles (UCLA).

UCLA Pro-Test, a group formed to support scientists who use animals in their studies, rallied about 400 people on 22 April - an estimated 40 animal activists also attended.

Pro-Test was formed by UCLA neuroscientist David Jentsch, whose car was firebombed in

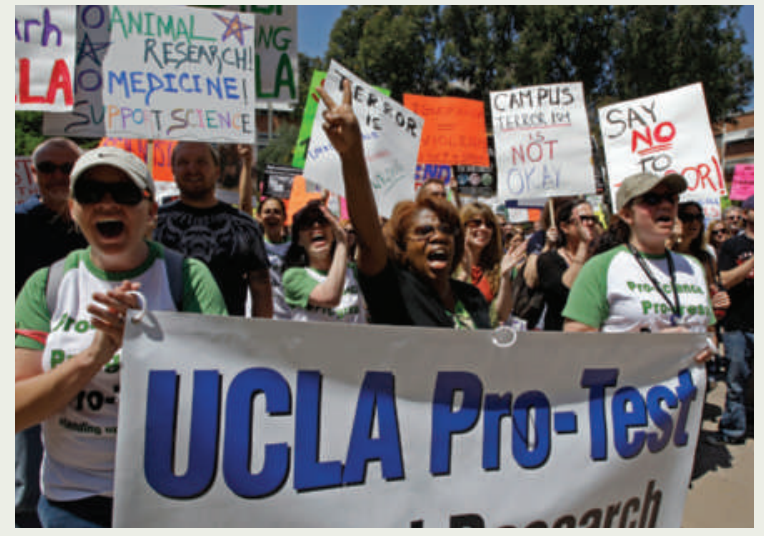

March by animal extremists reacting to recent arrests (see Nature 458,$813 ; 2009$ ).

to imagine. She did not seem to tire during nearly a week of public celebrations.

\section{Japan cuts red tape holding up stem-cell work}

A Japanese science ministry committee announced a plan on 22 April to loosen regulations on research involving embryonic stem cells (ES cells).

Scientists have complained about the current excessively bureaucratic system whereby they must seek permission for such work from a ministerial commission. The commission meets only rarely, and sometimes requests extra data from animal experiments to justify human research.

Under the new plan, expected to be approved by the Council for Science and Technology Policy, ES-cell researchers will only have to gain approval from their local institutional review board.

From May, the ministry will also free up the previously forbidden creation of cloned human embryos, although only for basic research into serious diseases.

\section{New UK coal must be partly 'clean'}

Any new coal-fired power station built in Britain must deploy carbon capture and storage (CCS) technology on 400 megawatts of its output, the country's energy and climate minister Ed Miliband announced on 23 April. If the Environment Agency judges CCS to be technically and economically 'proven', it would have to be retrofitted to cover the full output of new plants (typically 1,000-2,000 megawatts) by 2025 .

Miliband's speech followed the government's 22 April budget commitment to fund up to four CCS demonstrations. A levy raised from electricity suppliers - and ultimately consumers' bills - would raise the billions of pounds needed to support the projects, the Department of Energy and Climate Change said. A consultation this summer will firm up these plans.

The budget (see page 1084) also committed Britain to a cut in greenhousegas emissions of $34 \%$ from 1990 levels by 2020 , a milestone towards meeting the government's stated goal of an $\mathbf{8 0 \%}$ reduction in emissions by 2050 .

\section{Texas agencies sue over national disease lab}

A consortium of Texas agencies that lost a bid for the new US\$560-million-plus US National Bio and Agro-Defense Facility has sued in federal court to overturn the government's choice.

Earlier this year, the Department of Homeland Security finalized the selection of Kansas State University in Manhattan, Kansas, to host high-containment laboratories that will replace the ageing Plum Island Animal Disease Center in New York state (see Nature 456, 687; 2008).

On 23 April, the Texas Biological and Agro-Defense Consortium in San Antonio sued the department, alleging faulty decisions and political manipulation during the three-year competition process.

The consortium alleges that the department under-secretary who made the decision, Jay Cohen, was biased towards Kansas, and that the Kansas location is unsafe because of tornadoes and the cattle herds that could contract disease from an accidental release. A hearing is set for 8 June.

\section{Correction}

The News Feature 'The test of inflation' (Nature 458, 820-824; 2009) misstated the implications of Planck's hunt for B-modes. The sentence on page 824 should have read: 'If Planck fails to detect a B-mode signal, but does find evidence for non-Gaussianity, inflation would certainly be "in more of a corner", according to Turok.' 